\title{
Potential application of oil-suspended particulate matter aggregates (OSA) on the remediation of reflective beaches impacted by petroleum: a mesocosm simulation
}

\author{
Carine S. Silva ${ }^{1}$ - Olivia M. C. de Oliveira ${ }^{1,2}$ - Icaro T. A. Moreira ${ }^{1}$. \\ Antonio F. S. Queiroz ${ }^{1}$ - Marcos de Almeida ${ }^{1}$ - Jessica V. L. Silva ${ }^{1}$ • \\ Igor Oliveira da Silva Andrade ${ }^{1}$
}

Received: 1 October 2014 / Accepted: 11 August 2015

(C) Springer-Verlag Berlin Heidelberg 2015

\begin{abstract}
This paper presents the oil-suspended particulate matter aggregate (OSA) resulted from the interaction of droplets of dispersed oil in a water column and particulate matter. This structure reduces the adhesion of oil on solid surfaces, promotes dispersion, and may accelerate degradation processes. The effects of the addition of fine sediments (clay+silt) on the formation of OSA, their impact on the dispersion and degradation of the oil, and their potential use in recovering reflective sandy beaches were evaluated in a mesoscale simulation model. Two simulations were performed (21 days), in the absence and presence of fine sediments, with four units in each simulation using oil from the Recôncavo Basin. The results showed that the use of fine sediment increased the dispersion of the oil in the water column up to four times in relation to the sandy sediment. There was no evidence of the transport of hydrocarbons in bottom sediments associated with fine sediments that would have accelerated the dispersion and degradation rates of the oil. Most of the OSA that formed in this process remained in the water column, where the degradation processes were more effective. Over the 21 days of simulation, we observed a $40 \%$ reduction on average of the levels of saturated hydrocarbons staining the surface oil.
\end{abstract}

Responsible editor: Hongwen Sun

Carine S. Silva

carine.sntn@gmail.com; santanacarine@hotmail.com

1 Núcleo de Estudos Ambientais, Instituto de Geociências, Universidade Federal da Bahia, Campus de Ondina, 40170-290 Salvador, BA, Brazil

2 Instituto de Geociências, Departamento de Geofísica, Universidade Federal da Bahia, Campus de Ondina, 40170-290 Salvador, BA, Brazil
Keywords Aggregate oil · Suspended particulate matter . OSA · Total petroleum hydrocarbons $\cdot$ TPH $\cdot$ Sediment . Beach cleaning $\cdot$ Spill remediation

$\begin{array}{ll}\text { Abbreviations } \\ \text { SPM } & \text { Suspended particulate matter } \\ \text { OSA } & \text { Oil-suspended particulate matter aggregates } \\ \text { TPHs } & \text { Total petroleum hydrocarbons } \\ \text { TOC } & \text { Total organic carbon } \\ \text { LEPETRO } & \text { Laboratory for the Study of Petroleum } \\ \text { GC-FID } & \begin{array}{l}\text { Gas chromatography with a flame } \\ \text { ionization detector }\end{array} \\ \text { OM } & \text { Organic matter } \\ \text { PCA } & \text { Principal component analysis } \\ \text { HCA } & \text { Hierarchical cluster analysis } \\ \text { Pr } & \text { Pristane } \\ \text { Ph } & \text { Phytane } \\ \text { CAPES } & \text { Coordination for the Improvement } \\ & \text { of Higher Education Personnel }\end{array}$

\section{Introduction}

The beach's morphology and particle size and the hydrodynamic characteristics of its sedimentary material were analyzed in an integrated manner to classify the beach in stages of its beach evolution (Wright and Short 1984). As an extreme stage within the hydromorphological context, reflective beaches have a steep beach face, usually consist of coarse sand, and have a small stock of subaqueous sediments. Thus, waves dissipate low energy when interacting with the substrate and tend to break directly on the beach face, so there is a narrow surf zone where waves of ascending and plunging 
types form (Wright and Short 1984; Hoefel 1998; Calliari et al. 2003).

When an oil spill reaches the coast, it tends to move over the beach face in a similar way as sediment transport is carried by waves. Reflective beaches usually have a short beach face thus creating a smaller deposition area for oil. However, the predominance of larger sediment grain size, poor selection, and a low degree of compaction increases the penetration capability and permanence of the oil (ITOPF 2011).

Traditional methods of cleaning and remediating spills on beaches using absorbent materials, manual/mechanical removal, vacuum pumping, and blasting water (API 1985; ITOPF 2011) are problematic in regard to reflective beaches. The high mobility of the sediment prevents vehicular traffic, and the penetration of the oil in the sediment causes the removal of a large amount of sediment, so the impacts on biotic communities within the intertidal zone can be severe (Fricke et al. 1981; Owens 1999; Cantagallo et al. 2007).

An alternative that is also used is monitored natural attenuation, where weathering processes can degrade spilled oil. It is estimated that two important physical-chemical processes that occur during the natural process of cleaning a beach after an oil spill are as follows: (a) abrasion of the waves and (b) the interaction of oil with suspended particulate matter (SPM) forming oil-suspended particulate matter aggregates (OSA). OSA is a microscopic structure that can remain stable for weeks, formed from a natural process where oil droplets and sediment particles interact in a turbulent aqueous medium (Le Floch et al. 2002; Stoffyn-Egli and Lee 2002).

The importance of OSA formation in cleaning coastal environments has motivated many studies on aggregation in different conditions. In situ tests that accelerated the formation of OSA by increasing the concentration of sediment showed that the remobilization of sediment in the intertidal zone (surf washing) can effectively increase the formation of OSA and the dispersion of the oil (Lunel et al. 1996; Owens and Lee 2003; Sergy et al. 2003). However, the technique will only be effective if the sediment present characteristics that favor the aggregation.

Bandara et al. (2011) used a mathematical model to show that more than $80 \%$ of an oil spill can interact with the suspended particulate matter and that up to $65 \%$ of the oil can be removed from the water column by aggregation with SPM. However, laboratory experiments suggest that the adsorption of oil onto sediment occurs more significantly with clay and silt sediment particle sizes (Ajijolaiya et al. 2006; Guyomarch et al. 2002; Stoffyn-Egli and Lee 2002).

Thus, in high-energy coastal environments such as reflective beaches, sediments with high grain size have limited potential for the formation of OSA. Considering the hypothesis that fine sediments tend to transport offshore, the use of muddy sediment (clay + silt) can promote an increased interaction between oil and SPM, which may be used to increase the dispersion and degradation of the oil in these environments.

The purpose of this study was to evaluate the following in controlled laboratory conditions: (i) the effects of sediment on oil dispersion, (ii) the impact of OSA formation on oil degradation, and (iii) the potential use of fine sediments (clay+silt) in the recovery of reflective beaches impacted by oil.

\section{Materials and methods}

\section{Collection and characterization of sediments}

The sandy sediments used in the simulation model of reflective beaches were collected in the intertidal zone of the beach at Mar Moreno, adjacent to the mouth of the Jequitinhonha River, Bahia, Brazil. Recently, oil exploration blocks were granted in the region by the National Agency of Petroleum, Natural Gas and Biofuels (ANP 2005), resulting in a potential impact on the area. The morphodynamic characterization of the beach was performed using the parameters described in Table 1, with the beach being classified as reflective (Wright and Short 1984). Thus, it was possible to establish a correlation between the sediment used and the proposed morphodynamic stage in the model.

To accelerate the training of OSA, surface sediments were collected at six points in the mangrove estuary of the Una River, Bahia, Brazil. This environment is one of low energy with predominantly low granulometry sediments and high concentrations of organic matter.

Table 1 Characterization of the sediment sources from the beach of Mar Moreno and the municipality of Belmonte, Bahia, Brazil, used in the simulations of reflective beaches

\begin{tabular}{ll}
\hline Station & Belmonte \\
\hline Geographic coordinates & $12^{\circ} 42^{\prime} 09^{\prime \prime} \mathrm{S}, 38^{\circ} 55^{\prime} 17^{\prime \prime} \mathrm{W}$ \\
$\mathrm{Hb}(\mathrm{m})$ & 1.9 \\
$T(\mathrm{~s})$ & 10.2 \\
$\beta\left(^{\circ}\right)$ & 11.5 \\
$\mathrm{ws}$ & 0.1281 \\
Surf & Plunging \\
$\%$ coarse sand & 76.34 \\
$\%$ sand media & 2.07 \\
$\%$ fine sand & 18.78 \\
$\%$ silt & 2.73 \\
$\%$ clay & 0.09 \\
$\Omega$ & 1 \\
Morphodynamic stage & Reflective \\
\hline
\end{tabular}

$H b$ wave height before breaking, $T$ wave period, $\beta$ slope of the beach face, ws speed settling of the sediment, $\Omega$ dimensionless parameter Dean (1973) 
In both cases, the samples were carefully collected during low tide within the surface sediment $(0-10 \mathrm{~cm})$ and transferred to previously decontaminated aluminum containers. The samples were transported to the laboratory after collection and then stored in a freezer $\left(-20^{\circ} \mathrm{C}\right)$ in accordance with the preservation protocol for sediment samples (D3694-ASTM2011). Subsequently, the samples were dried in a cold lyophilizer for $72 \mathrm{~h}$ and homogenized to ensure uniformity. Only the samples from the mangrove sediments were sieved through a 230-mesh sieve to select clay and silt, because this is the size range most commonly associated with the formation of OSA (Sun and Zheng 2009). All the sediment samples were analyzed for select physical and chemical properties (Table 2).

The particle size distribution, total organic carbon (TOC) content, and organic matter (OM) were analyzed. The particle size distribution was determined using a Cilas 1064 laser diffraction particle size analyzer after removing the organic material with $30 \% \mathrm{H}_{2} \mathrm{O}_{2}$ and sodium hexametaphosphate, followed by stirring for $24 \mathrm{~h}$ to avoid flocculation in accordance with the method by Folk and Ward (1957). The organic matter content in the sediment was assessed using a method of potassium dichromate (EMBRAPA 2009). The available phosphorus was extracted by the method described by Olsen (EMBRAPA 2009) and analyzed by molecular spectrometry.

\section{Treatment of fine sediments (clay+silt)}

The sediments used to increase the aggregation rates were collected in a mangrove in an estuary of the Una River, Bahia, Brazil, because of their geochemical characteristics (Table 2). The sediment was dried by lyophilization and sieved through a 230-mesh sieve. Studies suggest that the dispersion of the stain is most effective when the application of the sediment is performed using a concentrated solution of

Table 2 Physical and chemical properties of the sediments used in the simulations

\begin{tabular}{lll}
\hline Parameters & Sediment-reflective beach & Fine sediments \\
\hline $\begin{array}{l}\text { Textural class } \\
\text { Particle size }\end{array}$ & Sandy & Silty clay \\
$\quad$ Coarse sand (\%) & 76.34 & \\
Medium sand (\%) & 2.07 & 0.00 \\
Fine sand (\%) & 18.78 & 0.00 \\
Particle & & 0.00 \\
Silt (\%) & 2.73 & \\
Clay (\%) & 0.09 & 94.21 \\
Organic matter (\%) & 0.10 & 5.79 \\
Organic carbon (\%) & 0.06 & 10.88 \\
Phosphorus (mg/L) & 0.00 & 6.34 \\
Carbonate (\%) & 24.51 & 9.47 \\
\hline
\end{tabular}

sediment. Therefore, a 100-g/L solution of fine sediments and seawater was prepared for use in the simulation units.

\section{Simulation of reflective beach}

The dynamics of the reflective beach environment were simulated by controlled waves acting within a specific morphology, sediments collected from a reflective beach and a natural seawater system. This study was conducted at the Laboratory for the Study of Petroleum-LEPETRO, which is linked to the Federal University of Bahia. The mesoscale experiment was used to evaluate the effects of the addition of fine sediments (clay+silt) in an oil spill on reflective sandy beaches. The simulation units were built in glass $(150 \times 50 \times 50 \mathrm{~cm})$. The morphology of the reflective beach was constructed using a graduated movable structure used to represent the slope of the beach (Fig. 1). The backgrounds of the simulation units were filled with sediment from the reflective beach. Controlled waves were created using a high-power pump. The presence of waves allows the transport of diluted and dispersed oil.

\section{Experimental design}

Two experiments were conducted separately: (i) in the absence of fine sediments (clay+silt) (simulation 1), where the aggregates form as a result of the oil-sediment interaction, and (ii) in the presence of fine sediments (clay+silt) used to accelerate the formation of OSA (simulation 2). Three replicates and a control experiment, where no sediment was added, were performed for each experiment. Approximately $100 \mathrm{~g}$ of crude oil was carefully and simultaneously poured over the surface of the seawater in the center of each simulation unit. The test oil was obtained from the production of the Recôncavo Basin, Bahia, Brazil. This consists of a light paraffinic oil with an API level of 40 and a low percentage of degradation (Fig. 2, Table 3). In the second simulation, approximately $10 \mathrm{~min}$ after pouring, the suspended artificial fine sediment was applied in each simulation unit (or seawater for the control unit). A suspension of $100 \mathrm{~g} / \mathrm{L}$ was sprayed over the butch about three times using a portable blaster.

In both simulations, samples were collected in a time series of $0,3,7,14$, and 21 days after the start of the experiment. Composite water samples $(600 \mathrm{~mL})$ were collected at two locations along the water column: approximately $5 \mathrm{~cm}$ below the surface and $5 \mathrm{~cm}$ above the bottom to assess variations in the vertical transport of OSA in the water column. The water samples were analyzed by gas chromatography with flame ionization detection (GC-FID) to quantify the oil that was dissolved and the fraction that was associated with SPM. A microscopic analysis of OSA was also performed for the temporal samples $(5 \mathrm{~mL})$ at both depths to assess their buoyancy. 
Fig. 1 Schematic representation of the mesocosm

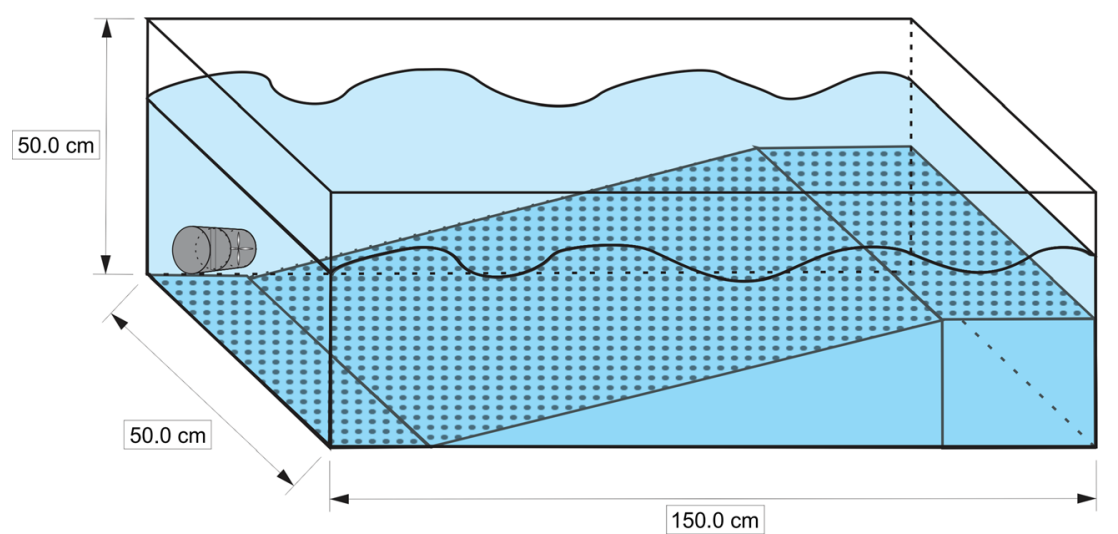

At the end of the experiment, oil and sediment samples were collected to estimate the extent of oil degradation.

\section{Formation of OSA by ultraviolet fluorescence spectroscopy}

Samples of $5 \mathrm{~mL}$ were collected for the observation and quantification of OSA formed throughout the experiment by transmitted light and epifluorescent ultraviolet illumination (excitation filter 340-390 nm, reflection short-pass filter $400 \mathrm{~nm}$, suppression pass filter $430 \mathrm{~nm}$ ) (Kepkay et al. 2002) using an Olympus model CKX41 inverted microscope. Photos of OSA with $\times 10$ magnification were recorded from a digital camera attached to the Olympus DP70 microscope. The images were processed using the software Image-Pro ${ }^{\circledR} 6.3$.

\section{Dispersion of oil and formation of OSA by GC-FID}

The samples were processed according to the method described by $\mathrm{Li}$ et al. (2007). The 600-mL samples $(600 \mathrm{~mL})$ collected from amber glass bottles in the simulation units were run through micro glass fiber filters $(0.5 \mu \mathrm{m})$ to separate the dissolved/colloidal phases and SPM. The filtrate was transferred to a separatory funnel to extract the hydrocarbons with dichloromethane (DCM) with the USEPA 3510C method (US EPA 1996). The solid phase was processed using Soxhlet extraction with dichloromethane (US EPA method $3540 \mathrm{C}$ ). The extracts from both phases were concentrated to $1 \mathrm{~mL}$ and analyzed by GC-FID to quantify the total petroleum hydrocarbons (TPHs) in the filtered phase (TPH mg per liter of water simulation unit) and the particulate phase (TPH mg per gram of solids). The TPHs were quantified using a Varian CP 3800 gas chromatograph equipped with a DB-5 capillary column (30 m length, $0.25 \mathrm{~mm}$ ID, $0.25 \mathrm{~lm}$ film thickness) and a flame ionization detector (FID). The chromatographic conditions are as follows: the injector temperature is $300{ }^{\circ} \mathrm{C}$; the starting temperature of the oven is $40{ }^{\circ} \mathrm{C}$ (held for $2 \mathrm{~min}$ ), which is increased at a rate of $10{ }^{\circ} \mathrm{C} / \mathrm{min}$ to $300{ }^{\circ} \mathrm{C}$ (held for another $2 \mathrm{~min}$ ); and the detector temperature is $300^{\circ} \mathrm{C}$. Helium is used as a carrier gas at a $1.0-\mathrm{mL} / \mathrm{min}$ flow rate, and a 10:1 split ratio was used. A standard solution was prepared from the same TPH (C10-C40) (ASTM D2887 and D6352). The analytical quality control and the quantification of the target compound's concentration values were in the range of $95 \%$ of the
Fig. 2 Gas chromatography (FID) of oil used in the study (Recôncavo Basin)

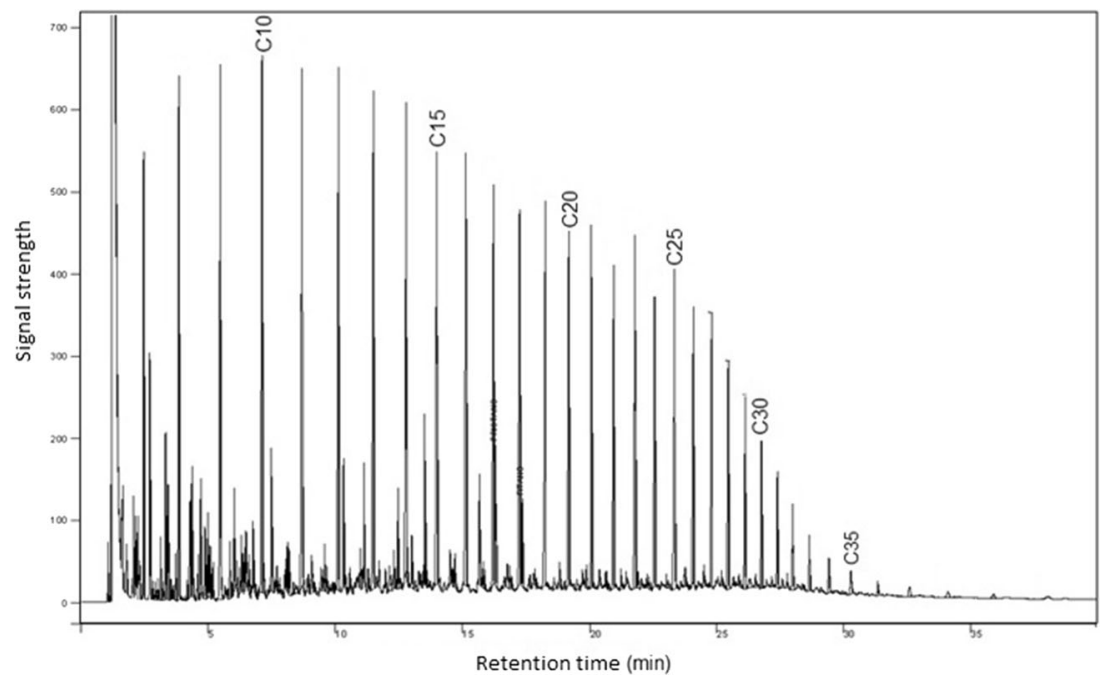


Table 3 Physical and chemical characterization of oil from the Recôncavo Basin used in the simulations

$\begin{array}{llll}\text { Oil type } & \text { Composition (\%) } & \\ & \text { Saturates } & \text { Aromatics } & \text { Resins and asphaltenes } \\ & 80 & 11 & 10 \\ \text { Recôncavo Basin oil } & \text { Physical properties of the oil of the Recôncavo Basin at } 15^{\circ} \mathrm{C} \\ & \text { Degree API } & \text { Gravity } \\ & 40 & 0.825\end{array}$

reference value assigned to the concentrations of selected hydrocarbons. The accuracy of the measurements obtained through repetition was less than $10 \%$ for all target compounds.

\section{Statistical analysis}

For the analysis and description of the sample data, descriptive statistics were performed to identify outliers. Subsequently, the Kolmogorov test was performed, along with the Smirnov test, to verify the normality of the data for the concentration of $\mathrm{TPH}$; the chi-square test indicated no significant difference between the variances of the samples. When the variance was homogeneous, ANOVA was applied to a single parametric classification, which showed significant differences between the simulations. Finally, multivariate statistical tests, such as principal component analysis, hierarchical cluster analysis, and Pearson's correlation, were performed. The analyses were performed using the STATISTICA ${ }^{\circledR} 9.0$ software (STATSOFT 2009).

\section{Results and discussion}

\section{Physical-chemical properties of the sediment}

The physical-chemical characteristics of the sediments are presented in Table 2 . The beach sediment was solely responsible for the aggregation in simulation 1 . This sediment has a bad selection and it is mostly composed of coarse sand fraction with a percentage of organic matter is $0.10 \%$. In contrast, the sediment used to increase the potential for aggregation has approximately $6 \%$ of its grains in the clay fraction, with the rest distributed in silt, and approximately $10 \%$ organic matter. Several studies indicate that OSA is formed in sediments with grains less than $5 \mu \mathrm{m}$, and more often below $2 \mu \mathrm{m}$, in size due to the higher specific surface area (Sun and Zheng 2009). However, their formation cannot be neglected in sediments with a particle size $>10 \mu \mathrm{m}$ (Sun and Zheng 2009).

However, in high-energy environments such as beaches, it is possible that the sand composes the SPM in the water column in the surf zone. Sorensen et al. (2014) analyzed the influence of physical and chemical parameters in the formation of OSA and verified that carbonate sands and quartz sands (commonly found on sandy beaches) of the same size fraction show similar levels of aggregation. This suggests that grain size is a dominant factor in controlling the adsorption of oil onto the SPM, with the mineralogical composition as a secondary factor. The study also concluded that such particles, due to their large size, may provide a route for the fast transfer of oil droplets to the bottom sediment.

In the case of fine sediment, Guyomarch et al. (2002) suggest that the formation of oil aggregates on SPM is driven by interactions between polar compounds in oil and negatively charged particles, especially clay. In addition, the presence of organic material coating the sediment increases the adsorption capacity of hydrophobic compounds (Muschenheim and Lee 2002).

\section{Distribution of particles in the simulation units}

The dynamics of the distribution of particles in the reflective beach simulation units were evaluated at two collection depths: subsurface (approximately $5 \mathrm{~cm}$ below the surface) and at depth (approximately $5 \mathrm{~cm}$ above the substrate). The temporal evaluation of the concentration of SPM in the absence and presence of fine sediments (clay + silt) is shown in Fig. 3.

The concentration of SPM available in the environment to interact with the oil is a key factor in aggregation. The increase in the formation of OSA with different sediment concentrations has been shown in several studies (Khelifa et al. 2005; Ajijolaiya et al. 2006; Sun et al. 2010). There is a direct relationship between the concentration of suspended sediments and oil droplets, which are stabilized by the formation of OSA.

The total concentrations of particles in simulation 1 averaged $30.18 \mathrm{mg} / \mathrm{L}$ at the surface at the beginning of the experiment. In the second simulation, where fine sediments were added, the average SPM surface reached values on the order of $520.00 \mathrm{mg} / \mathrm{L}$. From the time third three is no significant change in the concentrations of MPS at the two depths. By characterizing the interaction of oil/SPM offshore and coastal environments, Boehm (1987) estimated that at SPM concentrations ranging from 1 to $10 \mathrm{mg} / \mathrm{L}$, the rates of aggregation are very low. In contrast, considerable Considerable aggregation can occur at SPM concentrations 

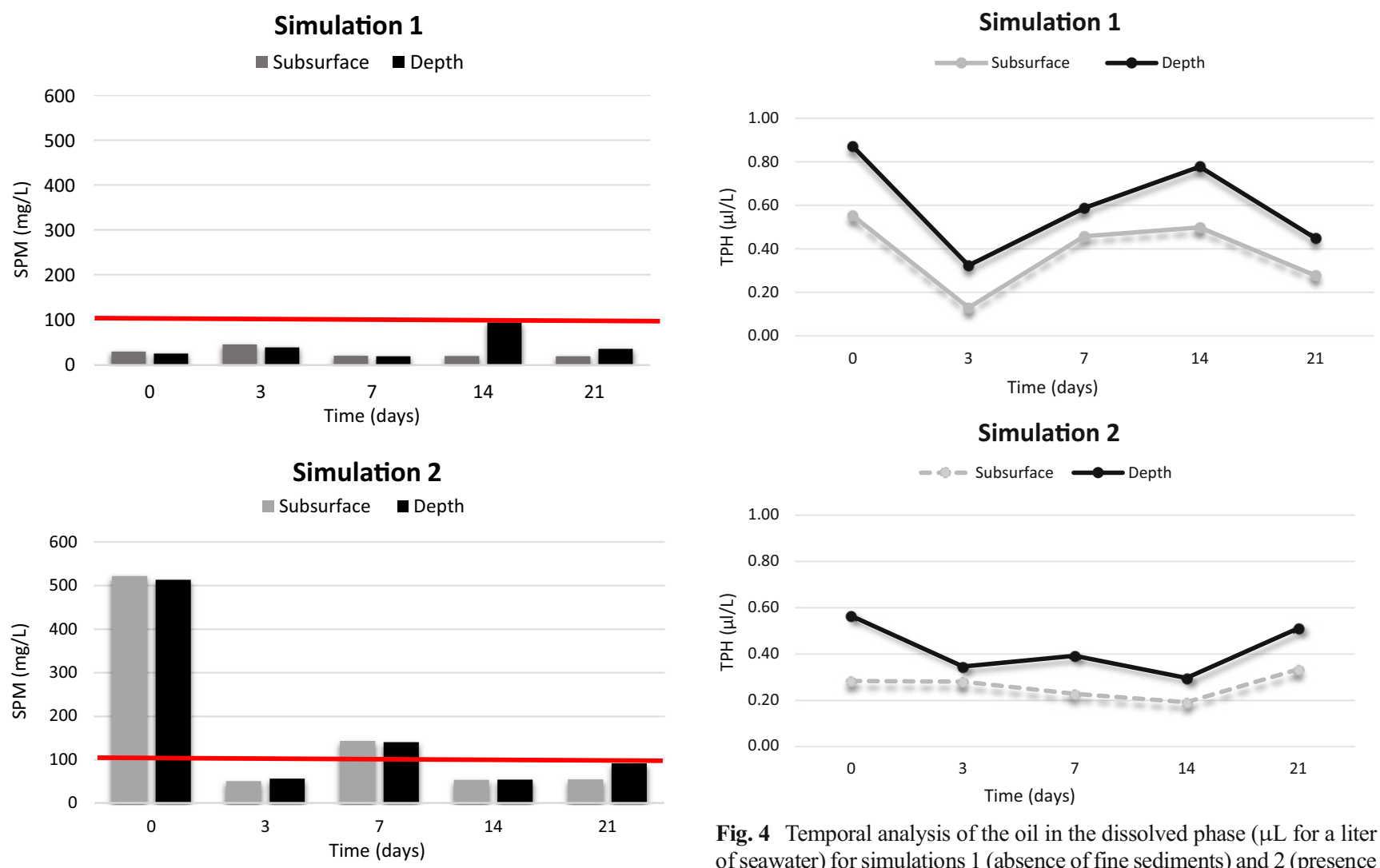

Fig. 3 Temporal distribution of suspended particulate matter in the absence of fine sediments (clay+silt) (simulation 1) and in the presence of fine sediments (simulation 2)

greater than $100 \mathrm{mg} / \mathrm{L}$, and the adsorption of oil droplet particles in suspension can be an effective mechanism for dispersion. Under these conditions, for the model of reflective beaches in simulation 1, the aggregation tends to be inefficient because of the low concentration of MPS. In beaches with similar characteristics, even the removal of contaminated sediment to the intertidal zone and the technique of surf washing would have a limited efficiency. In the second simulation, when the fine sediment was added, initial high concentrations of MPS can facilitate the formation of the OSA.

\section{Distribution of OSA in the water column}

The OSA that forms can remain on the surface of the water column (positive buoyancy), along the water column (neutral buoyancy), or within the sediment (negative buoyancy). The vertical distribution of the OSA will depend on its size, the ratio of oil and SPM for each aggregate, and the local hydrodynamic conditions (Sterling et al. 2004). The vertical transport of the oil dissolved in the water (Fig. 4) and the oil dispersed by sediment (Fig. 5) in the presence and absence of fine sediment $($ clay + silt) was quantified by analyzing the TPHs from composite samples of seawater collected in the

Fig. 4 Temporal analysis of the oil in the dissolved phase ( $\mu \mathrm{L}$ for a liter of seawater) for simulations 1 (absence of fine sediments) and 2 (presence of fine sediments). The results are presented in accordance with the average value $(n=4)$

subsurface $(5 \mathrm{~cm}$ below the surface $)$ and at depth $(5 \mathrm{~cm}$ above the bottom sediment).

In both simulations, the concentration of the particulate TPH associated with the sediment was significantly higher than that in the dissolved phase $(p<0.05)$ showing that the formation of OSA was relevant. The concentration of the TPH associated with the dissolved phase is due to the dissolution of the lightest compounds in seawater. There was a trend towards a reduction of these values over time in the subsurface and at depth, except for the surface in simulation 2. The oil concentrations in the dissolved phase in the water column were higher near the substrate, which is most likely related to the high rates of adsorption to the sediment surface. This confirms the higher concentration of the dissolved oil phase in the absence of fine sediment for both layers. Aggregation can stabilize the oil droplets and reduce their solubility in the water column ( $\mathrm{Li}$ et al. 2007).

Figure 5 shows that the presence of fine sediments (clay+ silt) significantly increased $(p<0.05)$ the concentration of the TPH associated with the particulate phase. The silt+clay dispersed the oil up to four times more compared with the sandy sediment. In both simulations, there is a trend of increasing concentrations of TPH in the particulate surface.

Guyomarch et al. (2002) suggest that the concentration of asphaltenes can be considered as a measure of the amount of polar compounds in the oil, supporting the hypothesis that 

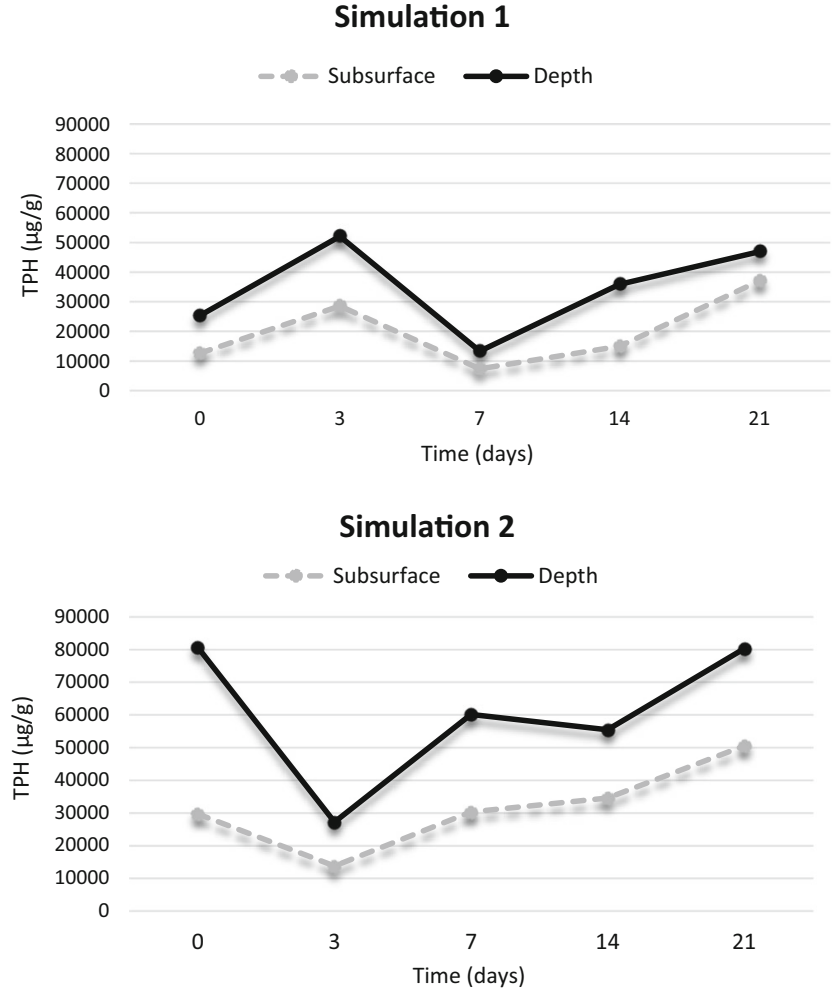

Fig. 5 Temporal analysis of the oil in the particulate phase ( $\mu \mathrm{g}$ for $\mathrm{g}$ of seawater) for simulations 1 (absence of fine sediments) and 2 (presence of fine sediments). The results are presented in accordance with the average value $(n=4)$

OSA formation is the result of interactions between polar compounds in the oil and particles in suspension. The Recôncavo Basin oil used in this study shows approximately $10 \%$ resins and asphaltenes (Table 3 ). In addition, after a spill of crude oil at sea, the lighter compounds are degraded due to evaporation and dissolution (especially in high-energy environments), thereby enriching the relative concentration of asphaltenes. Over time, the remaining oil will therefore have a greater propensity to adsorb particles in the sedimentary clay (Guyomarch et al. 2002) and sand fraction (Sorensen et al. 2014). There is an opposite trend when analyzing the log aggregation at depth, where concentrations of TPH tend to decrease with time. In both simulations, the concentrations associated with the particulate phase at depth are greater than at the surface. It is suggested that the oil-SPM interaction occurs at the surface and that, as a consequence of a change in density, the oil trapped in the OSA changes from positive buoyancy to neutral, carrying most of the OSA and forming the basis for the water column.

The effect of adding fine sediments into an oil dispersion in the water column simulation units can be assessed by the proportions of oil separated between the dissolved phases and aggregated over the simulations (Fig. 6). There has been a fluctuation in the partition ratio over time for each simulation. The values in general are larger at depth, reinforcing that

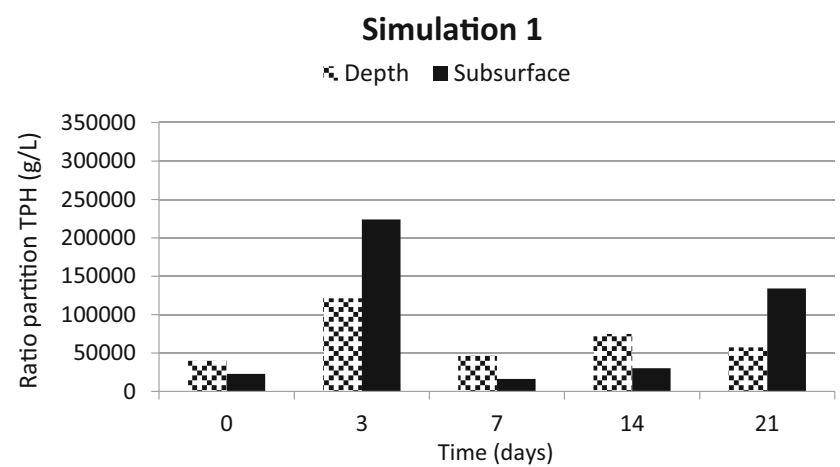

Simulation 2

septh Subsurface

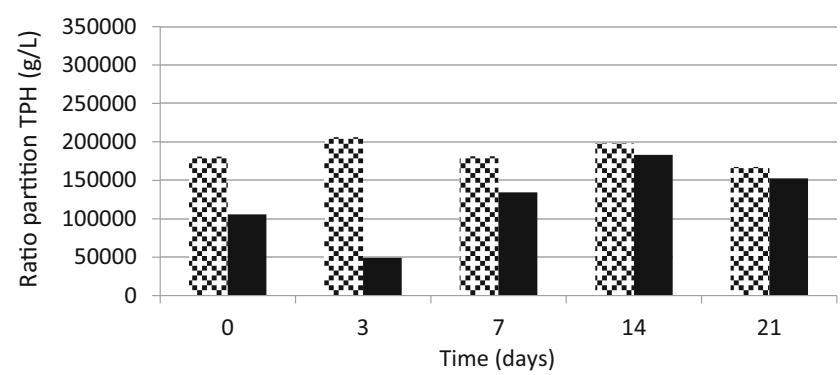

Fig. 6 Ratio partition between the oil dissolved and particulate phases in simulations 1 and 2

the TPH that was adsorbed by the sediment is transported along the water column. The process was intensified by the addition of fine sediments (clay+silt) in simulation 2 .

\section{Integrated assessment of dispersion of OSA in the water column}

The analysis of how the oil dispersed in SPM is influenced by the concentrations of organic matter, organic carbon, and phosphorus, and the physical-chemical parameters of temperature, $\mathrm{pH}$, salinity, and dissolved oxygen were assessed by principal component analysis (PCA) (Fig. 7). The analysis considered time 0 and time 21 . The first PC accounted for $54.75 \%$ of the total variance and the second accounted for $31.91 \%$, totaling approximately $85 \%$ of the total variance in the data.

The main variables that influenced the oil dispersed in SPM were the organic matter, organic carbon, phosphorus content, and salinity and $\mathrm{pH}$ of the water. The presence of organic matter/organic carbon can influence the fate of hydrophobic organic contaminants in aqueous environments (Backhus et al. 2003) by increasing the interaction strength between the hydrocarbons and sedimentary particles (Shen and Jaffe 2000), favoring the formation of OSA.

Nutrients such as phosphorus are limiting factors in the biodegradation of petroleum (Atlas 1997). The natural presence of reasonable concentrations of nutrients such as 


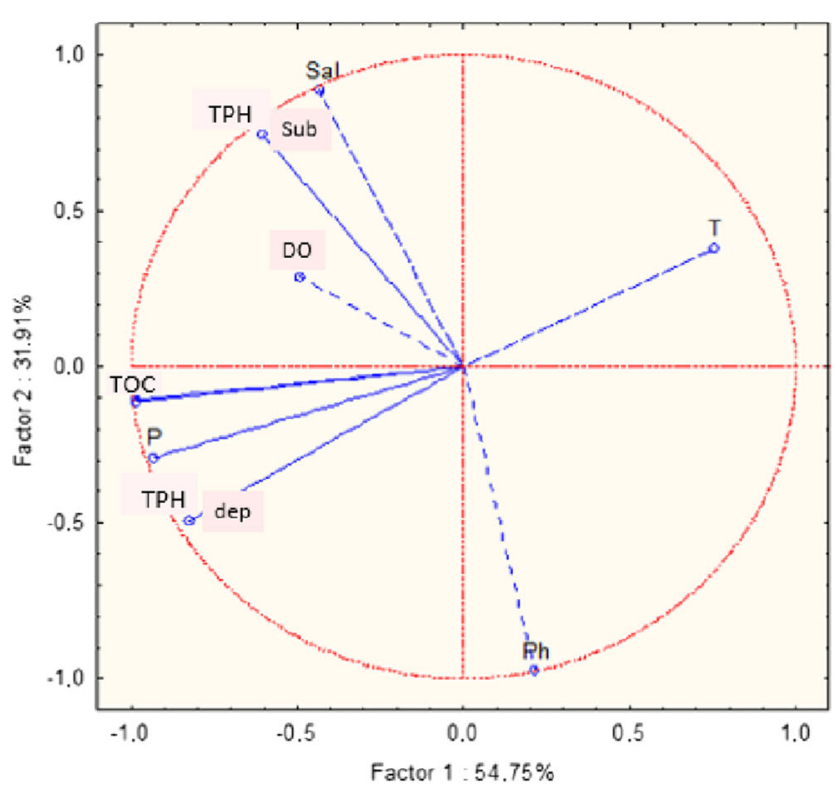

Fig. 7 Principal component analysis and analysis of hierarchical classification (factor $1 \times$ factor 2 ) between the oil associated with OSA and geochemical parameters at time 0 and time 21 days for the simulations in the absence and presence of fine sediments. TOC total

phosphorus in the sediment will positively influence the remediation process through encouraging microbial activity.

Other environmental factors such as salinity and $\mathrm{pH}$ can also affect the aggregation. According to Le Floch et al. (2002), salinity interferes with the flocculation of solid particles through ionic strength and modifies the properties of oil droplets, affecting the rate of OSA formation. In saline water, this process is more efficient because the presence of free ions reduces the electrostatic repulsion force between the sedimentary particles (negatively charged) and enhances the molecular attraction force, allowing a coalescence between the solid particles and polar compounds in the oil (Sun and Zheng 2009). During the simulations, the concentrations of TPH dispersed in SPM were independent of the amount of dissolved oxygen in the water.

A joint interpretation of PCA with the hierarchical classification analysis (HCA) (Fig. 7) established a relationship between the geochemical parameters and the simulations at each time investigated. For simulation 1, which did not have any fine sediments, the environmental characteristics of the water column were more important in the process at the initial time and the temperature and $\mathrm{pH}$ at the end time. At the initial time of simulation 2, the most important factors were the concentrations of organic matter/organic carbon, phosphorus, and hydrocarbon dispersed in SPM at the bottom of the water column. At the final time, the salinity of the water column and the concentrations of hydrocarbons dispersed in SPM on the surface were the most important. It is clear that the presence of fine sediments and their geochemical characteristics influenced the dispersion of the oil.

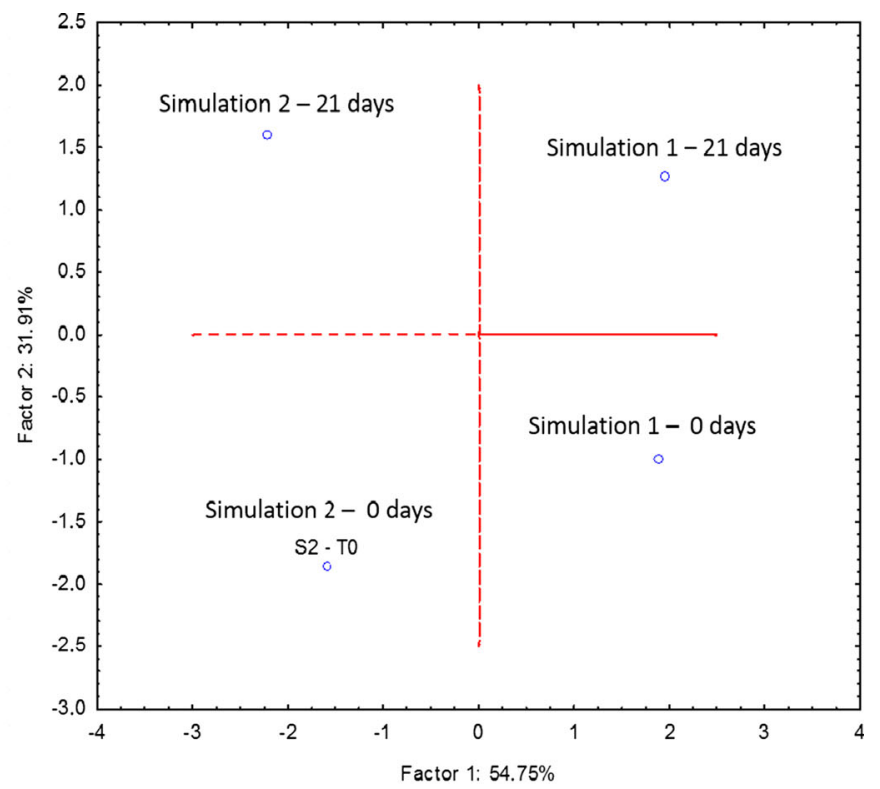

organic carbon, $P$ phosphorus, $T$ temperature, Sal salinity, $D O$ dissolved oxygen, $p H$ hydrogen potential, TPH sub dispersed oil by sediment in the subsurface, TPH dep dispersed oil sediment depth

The Pearson correlation matrix shows relationships among the influences of the variables (Table 4). A strong positive correlation between salinity and hydrocarbons dispersed in the SPM surface suggests that salinity favored the aggregation process. In fact, in both simulations, there was an increase in the salinity at time 21 relative to time 0 because of the evaporation of seawater. This corroborates the temporal assessment of the aggregation rates (Fig. 7).

At depth, the dispersion of oil as a function of the SPM has a strong correlation with the concentration of substance/ organic content and phosphorus. The salinity at a depth of $5 \mathrm{~cm}$ above the substrate appears to have a minor effect on aggregation. Khelifa et al. (2005) reported that the effect of salinity may be of minimal importance in terms of sediment with high organic matter content.

\section{OSA structure formed in the simulation of reflective beaches}

Epifluorescence microscopy was used to examine the OSA that formed. Two different structural types of OSA could be distinguished: droplet and amorphous. The droplets appear as dispersed oil (beads) with mineral particles attached to their surface (Fig. 8a, b). The amount of a droplet attached to SPM is highly variable. Although individual droplet aggregates are more commonly aggregates composed of several drops of oil, sometimes more than ten were observed (Fig. 8c, d). These multiple aggregates were previously reported in other studies (Omatoso et al. 2002; Stoffyn-Egli and Lee 2002). Amorphous aggregates are typically not spherical, 
Table 4 Pearson correlation matrix applied to the formation and dispersal of the OSA simulations on models of reflective beaches

\begin{tabular}{|c|c|c|c|c|c|c|c|c|c|}
\hline & $\mathrm{pH}$ & $T$ & Salt & OD & TPH sub & TPH dep & OM & TOC & $P$ \\
\hline $\mathrm{pH}$ & 1.00 & & & & & & & & \\
\hline$T$ & -0.15 & 1.00 & & & & & & & \\
\hline Salt & -0.94 & 0.10 & 1.00 & & & & & & \\
\hline OD & -0.48 & -0.70 & 0.34 & 1.00 & & & & & \\
\hline TPH sub & -0.82 & -0.02 & 0.97 & 0.28 & 1.00 & & & & \\
\hline TPH dep & 0.33 & -0.67 & -0.04 & 0.05 & 0.20 & 1.00 & & & \\
\hline $\mathrm{OM}$ & -0.10 & -0.73 & 0.35 & 0.38 & 0.55 & 0.90 & 1.00 & & \\
\hline TOC & -0.09 & -0.73 & 0.34 & 0.37 & 0.54 & 0.90 & 1.00 & 1.00 & \\
\hline$P$ & 0.10 & -0.71 & 0.18 & 0.21 & 0.41 & 0.97 & 0.98 & 0.98 & 1.00 \\
\hline
\end{tabular}

Italicized values with $p<0.05$

$O M$ organic matter, TOC total organic carbon, $P$ phosphorus, $T$ temperature, Salt salinity, $D O$ dissolved oxygen, $p H$ hydrogen potential, $T P H$ sub dispersed oil by sediment in the subsurface, TPH dep dispersed oil sediment depth

fluorescent irregular borders; instead, they are often elongated, curved, or even branched (Fig. 9a, b). The amorphous form of the OSA is controlled by the minerals included therein. The membranous type of OSA, described in detail by Stoffyn-Egli and Lee (2002) in the presence of montmorillonite, was not observed in any of the simulations.

It is possible that the interaction between the oil and the sandy sediment in seawater can be observed in Figs. 8a, b and $9 \mathrm{a}$, while the interaction between oil and fine sediments is observed in Figs. 8c, d and 9b. A significant increase in the concentration of OSA formed from the use of fine sediments is observed, which corroborates the data of gas chromatography, accompanied by a reduction in the size of these aggregates. In general, we can note that after the addition of fine sediments (clay + silt), the aggregates that form are smaller than in the absence of fine sediments.

\section{Oil transfer assessment in the bottom sediment}

Lee (2002) notes that, although some studies relate the oilparticle interaction with the physical transport of the spilled oil from the sea surface to the ocean floor, other studies have attributed the added buoyancy to a contribution of the oil in OSA, which allows for longer periods of suspension in the water column. The assessment of environmental change compartment OSA is important to investigate the potential impacts
Fig. 8 Examples of OSA observed in the interaction of the oil with the Recôncavo Basin sediments: the oil is bright (fluorescent), and sedimentary particles are darker. White light: (a) the droplet OSA type in simulation 1 ; (c) OSA multigotículas type in simulation 2. UV filter: (b) the droplet OSA type in simulation 1 ; (d) the OSA multigotículas kind in simulation 2
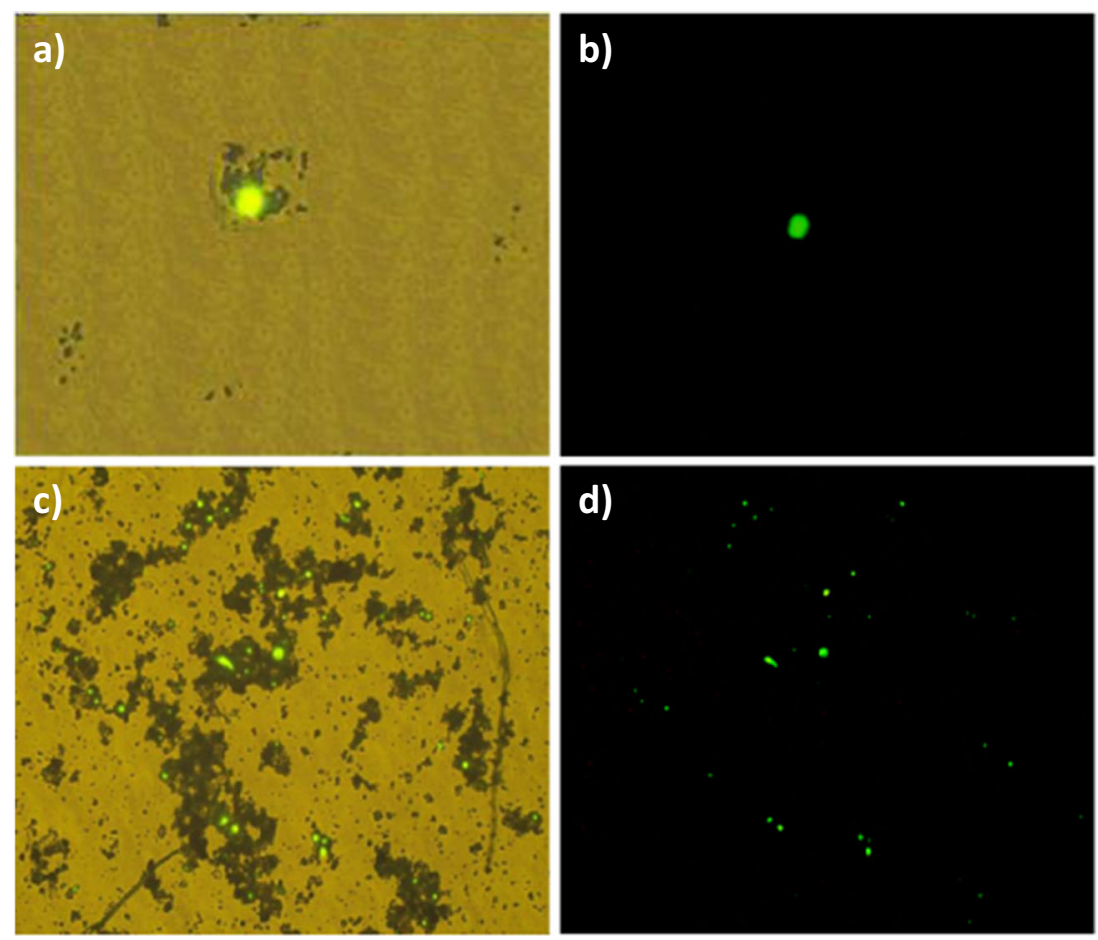
Fig. 9 Examples of OSA observed in the interaction of the oil with the Recôncavo Basin sediments: the oil appears bright (fluorescent) and sedimentary particles are darker. a OSA simulation in the amorphous type 1 and $\mathbf{b}$ OSA simulation in the amorphous type 2
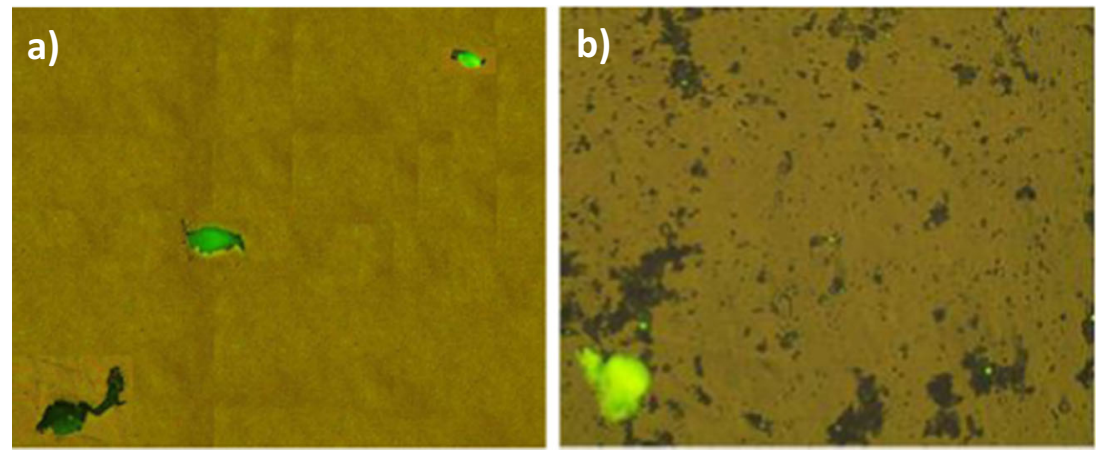

on planktonic and benthic biological communities and has a great reflection in the dispersed hydrocarbon degradation.

Figure 10 shows the concentrations of TPH in the bottom sediments of the simulation units before the oil spill and at the end of the simulations (21 days). In the absence of fine sediments, the average concentration of TPH increased from $184.28 \pm 22.23 \mu \mathrm{g} / \mathrm{g}$ at the beginning of the experiment to $197.46 \pm 52.97 \mu \mathrm{g} / \mathrm{g}$ after 21 days. In the presence of fine sediment, the TPH concentrations in the sediment ranging from an average of $162.32 \pm 25.40 \mu \mathrm{g} / \mathrm{g}$ at the beginning of the experiment to $110.21 \pm 21.77 \mu \mathrm{g} / \mathrm{g}$ at the end of the simulation.

Figure 11 shows the concentrations of TPHs and pristane and phytane isoprenoids along with the pristane/phytane ratio. These geochemical indices can be used to clarify if the organic matter associated with the bottom sediment has a petrogenic or natural origin. Many studies suggest that a high proportion of the isoprenoids pristane and phytane indicates a biogenic source with a large supply of recent organic matter (Volkman et al. 1992; Readman et al. 2002; Silva et al. 2013), and the prevalence of phytane indicates the presence of organic matter from a petroleum origin.

In the first simulation, at time 0 , it is observed that the value of the pristane/phytane ratio was always below 1, suggesting a petrogenic input. However, it is noteworthy that the concentrations of phytane were low (Table 5). The presence of this isoprenoid is typically associated with oil inputs and is rarely

目 Time 0 days $\square$ Time 21 days

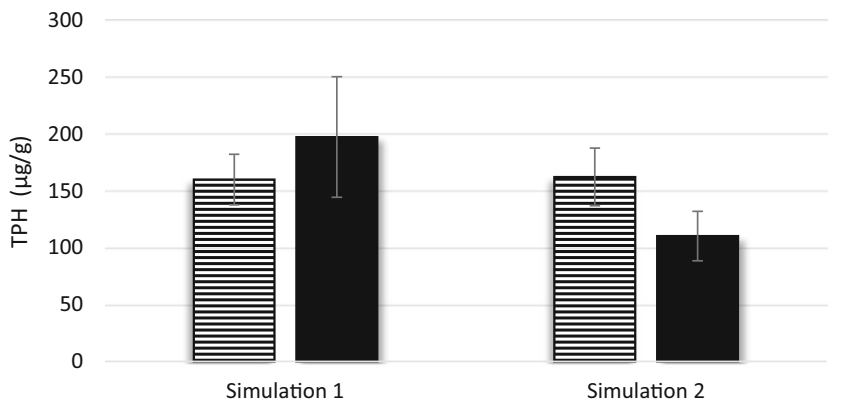

Fig. 10 Average concentration of TPH $(\mu \mathrm{g} / \mathrm{g})$ in the bottom sediment unit simulation model of reflective beaches, in the absence (simulation 1 ) and presence (simulation 2) of fine sediments related to a biogenic source (Volkman et al. 1992). It is also observed that the eigenvalues are low for the pristane and phytane equivalent, so the ratio becomes lower even from a small input of organic matter associated with the sandy sediment.

In comparison with time 21, an increase in the levels of TPH is observed. However, the reason pristane/phytane remains less than 1 is because there is a higher concentration of isoprenoids. The entrance of phytane into the substrate showed the petrogenic origin of the organic matter, indicating that the transfer had occurred for the OSA bottom sediment. Recently, Sorensen et al. (2014) investigated the interaction of droplets of dispersed oil in seawater with sandy sediments, typically found on beaches, and suggested that the association of oil with this type of sediment could provide a route for oil transportation through the water column to the bottom sediment. The problem associated with changing the environmental chamber is the increased persistence in the oil because the degradation rate is reduced. The sediments are considered to be the ultimate fate of many anthropogenic contaminants (Venturini 2004). In addition, possible adverse effects include the presence of hydrocarbons, which can cause benthic ecosystem effects (Moreira 2014; Carls et al. 2008).

In the second simulation at time 0 , the concentration of hydrocarbons in fine sediment (clay+silt) is composed of

\section{Oil slick}

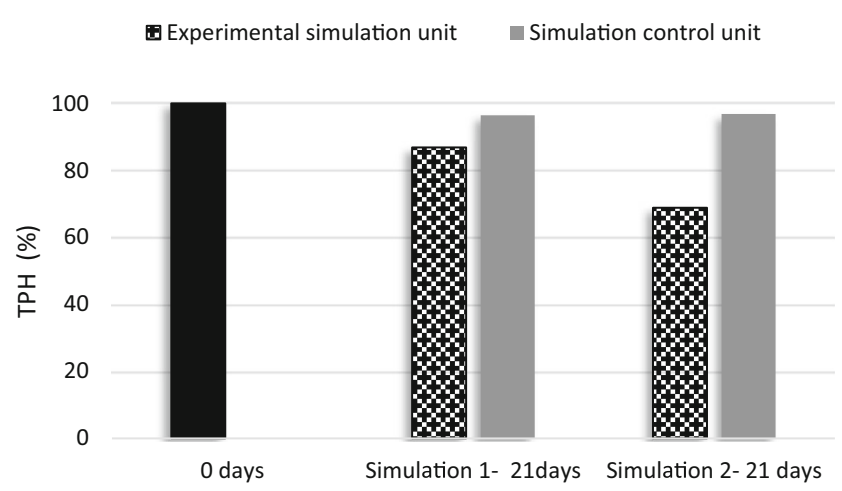

Fig. 11 TPH mean concentration (\%) from the oil slick on the surface of simulation units 1 and 2 and their respective controls $(n=4)$ 
Table 5 Hydrocarbon concentrations $(\mu \mathrm{g} / \mathrm{g})$, pristane and phytane isoprenoids $(\mu \mathrm{g} / \mathrm{g})$, and pristane/phytane ratio determined in sediments used in the simulations at baseline and end of the simulation

\begin{tabular}{lllll}
\hline Simulation/time & TPH & Pristane & Phytane & P/F \\
\hline Simulation 1 (0 day) & 169.94 & 0.13 & 0.20 & 0.63 \\
& 159.76 & 0.15 & 0.26 & 0.58 \\
Simulation 1 (21 days) & 150.14 & 0.23 & 0.31 & 0.75 \\
& 256.13 & 0.73 & 0.81 & 0.91 \\
& 136.98 & 0.83 & 0.92 & 0.90 \\
& 230.61 & 0.88 & 0.83 & 1.05 \\
Simulation 2 (0 day) & 217.41 & 0.72 & 0.78 & 0.93 \\
& 146.19 & 0.21 & 0.27 & 0.77 \\
& 183.62 & 3.11 & 0.92 & 3.38 \\
& 134.21 & 2.20 & 0.82 & 2.67 \\
& 169.14 & 1.94 & 1.03 & 1.87 \\
& 73.64 & 3.45 & 0.94 & 3.67 \\
& 122.56 & 3.49 & 0.98 & 3.55 \\
& 108.14 & 2.57 & 0.86 & 3.01 \\
& 118.13 & 1.83 & 0.61 & 3.00 \\
& 128.62 & 3.51 & 0.79 & 4.43 \\
\hline
\end{tabular}

organic matter of biogenic origin, likely the product of the decomposition of mangrove plants associated with the collection region. Comparing the results with those of time 21, there is no significant change in the levels of TPH, pristane, and phytane. The pristane/phytane ratio indicates the presence of organic matter of natural origin. Thus, the presence of fine sediments in the reflective beach model as a stimulus to the formation of OSA was not associated with increased concentrations of TPH in the bottom sediments of the simulation units.

\section{Assessment of the degradation of the oil slick}

Some studies suggest that OSA formation not only aids in the dispersion of the oil but also accelerates the rate of degradation because they are controlled in part by the accessibility of the oil to surfaces of bacteria, nutrients, and oxygen (Lee et al. 1996; Lee et al. 1997; Weise et al. 1999).

A comparison of the mean levels of degradation in the surface oil slick in the absence (simulation 1) and in the presence of fine sediments (simulation 2) is shown in Fig. 11. A comparison of the levels of TPHs presented on day 0 compared to day 21 shows that the degradation of the hydrocarbons was more efficient in the presence of fine sediments. Still, it should be emphasized that the levels of degradation at the end of 21 days are low: 13 and $31 \%$ for the simulations in the absence and presence of fine sediments, respectively. Although an efficient dispersion of the oil in the SPM has been observed throughout the 3 weeks of the experiment, the degradation kinetics of these compounds tends to be slower; thus, it is possible that the period of the simulations was a limiting factor for the research.

Still, the first two factors, alone or together, can respond to a difference in the levels of degradation: (i) in the presence of nutrients associated with fine sediment and (ii) increasing the aggregation due to the presence of fine sediments. The oil may serve as the main carbon source for the growth of microorganisms, facilitating the degradation of these compounds in the environment. However, there is a need for other macronutrients, including nitrogen and phosphorus. The fine sediments have a higher degree of added parameters evaluated, including phosphorus. This allows us to assume that nutrient enrichment from the fine sediments in the system may have contributed to further deterioration in simulation 2. However, it is verified in simulation 1 that even in the absence of fine sediments, taking nutrients to limit degradation had a greater impact than the spot oil unit in the control simulation (without any sediment).

Wood et al. (1998) evaluated the influence of OSA on the Sea Empress spill and concluded that the association of particles and bacteria in suspension can be more efficient for the biodegradation of the dispersed oil droplets than bacteria alone, and suspended nutrients seem less important for biodegradation than the level of dispersion in the presence of sediments. The OSA training itself appears to be sufficient to stimulate the growth of bacteria without the need for additional nutrients. It is assumed that increasing the available surface area per volume of oil makes the oil more accessible to hydrocarbonoclastic bacteria and also allows greater contact with oxygen, thus accelerating the degradation process (Lee et al. 1996; Owens and Lee 2003; Weise et al. 1999). Thus, the presence of nutrients and aggregation associated with SPM seem to have a synergistic effect on the degradation of oil.

The selective removal of fractions of saturates, aromatics, resins, and asphaltenes from the surface degradation of oil hydrocarbons was assessed at the beginning and end of the experiment in the absence (simulation 1) and presence

\section{Oil degradation}

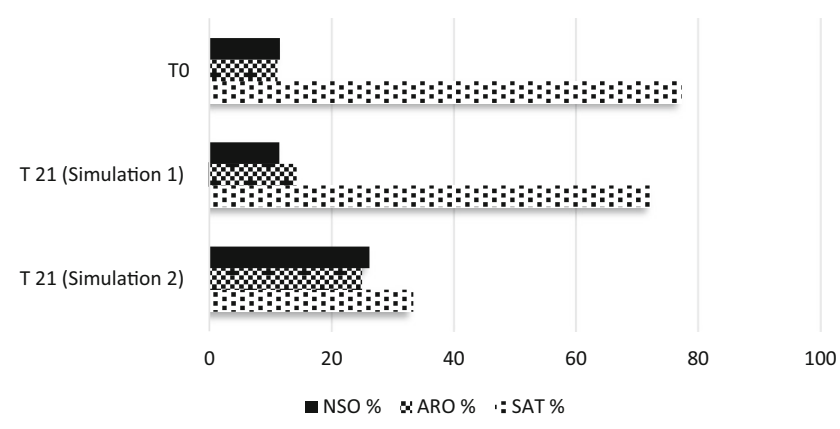

Fig. 12 Average distribution of the fractions of saturated compounds, aromatics, resins, and asphaltenes (\%) from the oil slick surface at time 0 and time 21 in simulations 1 and 2. SAT saturated, ARO aromatic, NSO resins and asphaltenes 
(simulation 2) of fine sediments (Fig. 12). The relative enrichment of the heavier oil compounds allows for pellet adsorption-enhanced oil (Guyomarch et al. 2002). This process was verified with greater intensity in the presence of silt, where the formation of OSA was also higher, suggesting a correlation between the level of enrichment of the heavier oil fractions (aromatics, asphaltenes, and resins) and the oilSPM interaction.

\section{Conclusions}

This study evaluated the effects of using fine sediments from reflective beaches in mesoscale models to disperse oil, the impact of OSA in the formation of oil degradation, and the potential use in the recovery of fine sediment-reflective beaches impacted by oil.

The investigation of the aggregation and its impact on the formation and degradation of OSA stains based only on sediments collected from a reflective beach aimed to present a scenario where there were no external stimuli for the formation of OSA. In this sense, even that the sediment grain size is relatively larger, in a high-energy coast, this type of SPM is certainly found and serves as a substrate for the adsorption of the oil spilled. According to this configuration, an oil-sandy sediment interaction occurs (to a lesser extent than with the addition of fine sediment); however, the process is associated with the transport of hydrocarbons from the water column to the bottom sediment. This change in the environmental chamber should be viewed as a negative factor, because the oil associated with the bottom sediment has a tendency to increase the persistence in the environment while causing a series of impacts to benthic organisms.

The influence of the formation of OSA on the degradation of surface stains was not observed in the absence of fine sediments, where it has a large impact. It is possible that low concentrations of nutrients associated with sandy sediments have a limited influence.

The application of fine sediments on reflective beaches can be a viable alternative. The results show that the presence of silt in the reflective beach model reduced the dissolution of the oil in the water column, stabilized the droplets, and promoted a significant increase in oil dispersion. Most OSA that formed had neutral buoyancy; it is not an effective means of hydrocarbon transport from the water column to the pellet. Keeping OSA in the water column longer means the effects of the oil's transport and degradation due to weathering processes are most effective in water. Factors such as the concentrations of organic matter and phosphorus and the salinity of the water played a role in the degree of adsorption between the SPM and the spilled oil. A breakthrough in the degradation levels of the surface stains from saturated hydrocarbons was also observed during the 21 days of simulation.
The formation of natural or stimulated OSA in coastal environments and its consequences is a complex process. A number of gaps remain to be filled. The influence of the formation of OSA should be evaluated from a higher temporal series and from microbiological analyses, where it is possible to associate the stimulus aggregation of biodegradation. Understanding the role of nutrients associated with sediment in the oil degradation should be further investigated.

No doubt the use of fine sediments in reflective sandy beaches in the dispersion and degradation of oil should be considered carefully. Although beaches are the same morphodynamic-stage environments with a similar configuration, local parameters such as the type and concentration of SPM, the transport direction of the currents, and the forecast of the final destination of the material should be assessed.

Acknowledgments This study was performed with financial support from the Coordination for the Improvement of Higher Education Personnel (CAPES) and Queiroz Galvão Exploração e Produção S.A.

\section{References}

Ajijolaiya LO, Hill PS, Khelifa A, Islam RM, Lee K (2006) Laboratory investigation of the effects of mineral size and concentration on the formation of oil-mineral aggregates. Mar Pollut Bull 56:920-927

Agência Nacional do Petróleo (ANP) (2005) Brasil round 7. http://www. anp.gov.br/brasilrounds/round7/round7/areas_oferecidas.asp. Accessed February 2014

American Petroleum Institute (API) (1985) Oil spill cleanup: options for minimizing adverse ecological impacts. Health and Environmental Science Department, Washington, p 580

Atlas RM, Raymond RL (1997) Stimulated petroleum biodegradation. Crit Rev In Microbiol 5(4):371-386

Backhus DA, Golini C, Castellanos E (2003) Evaluation of fluorescence quenching for assessing the importance of interactions between nonpolar organic pollutants and dissolved organic matter. Environ Sci Technol 37(20):4717-4723

Bandara UC, Poojitha DY, Xie H (2011) Fate and transport of oil in sediment laden marine waters. J Hydro Environ Res 5:145-156

Boehm PD (1987) Transport and transformation processes regarding hydrocarbon and metal pollutants in offshore sedimentary environments. In: Boesch DF, Rabalais NN (eds) Long-term environmental effects of offshore oil and gas development. Elsevier Applied Science, London, pp 233-287

Calliari LJ, Muehe D, Hoefel FG, Toldo Jr EE (2003) Morfodinâmica praial: uma breve revisão. Rev Bras Oceanogr 50:63-78

Cantagallo C, Milanelli JCC, Dias-Brito D (2007) Limpeza de ambientes costeiros brasileiros contaminados por petróleo: uma revisão. PanAm J Aquat Sci 1:1-12

Carls MG, Holland L, Larsen M, Collier TK, Scholz NL, Incardona JP (2008) Fish embryos are damaged by dissolved PAHs, not oil particles. Aquat Toxicol 88(2):121-127

Dean RG (1973) Heuristic models of sad transport in the surf zone. Proceedings of Conference on Engineering Dynamics in the Coastal Zone, p.208-214

Fricke AH, Henning HF-KO, Orren MJ (1981) Relationship between oil pollution and Psammolittoral meiofauna density of two South African beaches. Mar Environ Res 5:59-77 
Guyomarch J, LE Floch S, Merlin F (2002) Effect of suspended mineral load, water salinity and oil type on the size of oil-mineral aggregates in the presence of chemical dispersant. Spill Sci Technol Bull 8(1): 95-100

Hoefel FG (1998) Morfodinâmica de praias arenosas oceânicas: uma revisão bibliográfica, 1st edn. Editora da UNIVALI, Itajaí, p 92

International Tanker Owners Pollution Federation (ITOPF) (2011) Shoreline clean up. http://www.itopf.com. Accessed December 2013

Kepkay PE, Lee K, Stoffyn-Egli P (2002) Application of ultraviolet fluorescence spectroscopy to monitor oil-mineral aggregate formation. Spill Sci Technol Bull 8(1):101-108

Khelifa A, Stoffyn-Egli P, Hill PS, Lee K (2005) Effects of salinity and clay type on oil-mineral aggregation. Mar Environ Res 59: 235-254

Le Floch S, Guyosarch J, Merlin FX, Stofyn-Egli P, Dixon J, Lee K (2002) The influence of salinity on oil-mineral aggregate formation. Spill Sci Technol Bull 8(1):65-71

Lee K (2002) Oil-particle interactions in aquatic environments: influence on the transport, fate, effect and remediation of oil spills. Spill Sci Technol Bull 8(1):3-8

Lee K, Weise AM, St-Pierre S (1996) Enhanced oil biodegradation with mineral fine interaction. Spill Sci Technol Bull 3(4):263-267

Lee K, Lunel T, Wood P, Swanneu R, Stoffyn-Egli P (1997) Shoreline cleanup by acceleration of clay-oil flocculation processes. In: Proc. Int. Oil Spill Conf. American Petroleum Institute Publication $\mathrm{N}^{\circ}$. 4651, Washington, DC, U.S.A, pp 235-240

Li Z, Kepkaya P, Lee K, Kinga T, Boufadelb MC, Venosa AD (2007) Effects of chemical dispersants and mineral fines on crude oil dispersion in a wave tank under breaking waves. Mar Pollut Bull 54: 983-993

Lunel TK, Lee K, Swannell R (1996) Shoreline clean up during the Sea Empress incident: the role of surf washing (clay-oil flocculation), dispersants and bioremediation. In: Proceedings of the 19th 794 Arctic and Marine Oil Spill Program (AMOP) Technical Seminar. Environment Canada, Ottawa, Ontario, p. 1521-1540

Moreira ITA (2014) Investigação de possíveis impactos ecológicos do petróleo sobre comunidades biológicas estuarinas na Baía de Todos os Santos e no sul da Bahia: OSA como uma ferramenta norteadora. Tese de Doutorado em Geologia Marinha, Instituto de Geociências, Universidade Federal da Bahia, p.207

Moreira ITA, Oliveira OMC, Triguis JA, Dos Santos AMP, Queiroz AFS, Martins CMS, Silva CS, Jesus RS (2011) Phytoremediation using Rizophora mangle L. in mangrove sediments contaminated by persistent total petroleum hydrocarbons (TPH's). Microchem J 99:376382

Moreira ITA, Oliveira OMC, Triguis JA, Queiroz AFS, Ferreira SLC, Martins CMS, Silva ACM, Falcão BA (2013) Phytoremediation in mangrove sediments impacted by persistent total petroleum hydrocarbons (TPHs) using Avicennia schaueriana. Mar Pollut Bull 67(1): $130-136$

Muschenheim DK, Lee K (2002) Removal of oil from the sea surface through particulate interactions: review and prospectus. Spill Sci Technol Bull 8:9-18

Niu H, Li Z, Lee K, Kepkay P, Mullin JV (2010) Modelling the transport of oil-mineral-aggregates (OSAs) in the marine environment and assessment of their potential risks. Environ Model Assess 3:10-25

NOAA. National Oceanic and Atmospheric Administration (1999) Screening quick reference tables. Hazmat Report, v. 99, n.1. NOAA, Washington, $\mathrm{p} 12$

Omotoso OE, Munoz VA, Mikula RJ (2002) Mechanisms of crude oilmineral interactions. Spill Sci Technol Bull 8(1):45-54

Owens, E. H. Evaluation of shoreline cleaning versus natural recovery: the Metula spill and the Komi operations. Proceedings International
Oil Spill Conference, American Petroleum Institute, Washington, D.C., Publication Number 4620, p. 503-509, 1999

Owens EH, Lee K (2003) Interaction of oil and mineral fines on shorelines: review and assessment. Mar Pollut Bull 47:397-405

Readman JW, Fillmann G, Tolosa I, Bartocci J, Villeneuve JP, Catinni C, Lee LD (2002) Petroleum and PAH contamination of the Black Sea. Mar Pollut Bull 44:48-62

Santas R, Santas P (2000) Effects of wave action on the bioremediation of crude oil saturated hydrocarbons. Mar Pollut Bull 40(5):434-439

Sergy GA, Guénette CC, Owens EH, Prince RC, Lee K (2003) In-situ treatment of oiled sediment shorelines. Spill Sci Technol Bull 8(3): 237-244

Shen L, Jaffé R (2000) Interactions between dissolved petroleum hydrocarbons and pure and humic acid-coated mineral surfaces in artificial seawater. Mar Environ Res 49:217-231

Silva CS, Moreira ITA, Oliveira MC, Queiroz AFS, Garcia KS, Falcão BA, Escobar NFC, Rios MC (2013) Spatial distribution and concentration assessment of total petroleum hydrocarbons in the intertidal zone surface sediment of Todos os Santos Bay, Brazil. Environ Monit Assess 186(2):1271-1280

Sorensen L, Melbye AG, Booth MA (2014) Oil droplet interaction with suspended sediment in the seawater column: influence of physical parameters and chemical dispersants. Mar Pollut Bull 78:146-152

STATSOFT Inc (2009) STATISTICA for the Windows operating system. Release 9. EUA, StatSoft., Tulsa

Sterling Jr MC, Bonner JS, Ernest ANS, Page CA, Autenrieth RL (2004) Characterizing aquatic sediment-oil aggregates using in situ instruments. Mar Pollut Bull 48:533-542

Stoffyn-Egli P, Lee K (2002) Formation and characterization of oil- mineral aggregates. Spill Sci Technol Bull 8(1):31-44

Sun J, Zheng AX (2009) A review of oil-suspended particulate matter aggregation - a natural process of cleansing spilled oil in the aquatic environment. J Environ Monit 11:1801-1809

Sun J, Khelifa A, Zheng X, Wang Z, So LL, Wong S, Yang C, Fieldhouse B (2010) A laboratory study on the kinetics of the formation of oilsuspended particulate matter aggregates using the NIST-1941b sediment. Mar Pollut Bull 60:1701-1707

Tolosa I, DE Mora S, Sheikholeslami MR, Villeneuve JP, Bartocci J, Cattini C (2004) Aliphatic and aromatic hydrocarbons in coastal Caspian Sea sediments. Mar Pollut Bull V 48:44-60

United States Environmental Protection Agency (US EPA) (1996) Method 3510c: separatory funnel liquid-liquid extraction. http:// www.epa.gov/epawaste/hazard/testmethods/sw846/pdfs/3510c.pdf. Accessed February 2014

Venturini N, Tommasi LR, Bícego MC, Martins CC (2004) Characterization of the benthic environment of a coastal area adjacent to an oil refinery, Todos os Santos Bay (NE-Brazil). Braz J Oceanogr 52(2):123-134

Volkman JK, Holdsworth DG, Neill GP, Bavor Jr HJ (1992) Identification of natural, anthropogenic and petroleum hydrocarbons in aquatic sediments. Sci Total Environ 112:203-219

Walkley A (1947) A critical examination of a rapid method for determining organic carbon $\mathrm{m}$ soils: effect of variations in digestion conditions and of inorganic soil constituents. Soil Sci 63:251-902, 263

Ward WC, Folk RL (1957) Brazos River bar: a study in the significance of grain size parameters. J Sediment Petrol 27:3-26

Weise AM, Nalewajko C, Lee K (1999) Oil-mineral fine interactions facilitate oil biodegradation in seawater. Environ Technol 20:811-824

Wood PA, Lunel T, Swannell DF, Lee K, Stoffyn-Egli P (1998) Clay-oil flocculation during surf washing at the Sea Empress incident, Proceedings of 21 st Arctic and Marine Oils Spill Program Technical Seminar, Edmonton

Wright LD, Short AD (1984) Morphodynamics variability of surf zones and beaches: a synthesis. Mar Geol 56:93-118 